\title{
DESIGNATION OF GEOSITES- PROPOSALS FOR GEOPARKS IN GREECE
}

\author{
Theodosiou Ir. \\ Institute of Geology and Mineral Exploration (IGME), Spyrou Loui 1, Olympic village, \\ Entrance C, 13677 Acharnai -Greece,ren@igme.gr
}

\begin{abstract}
During the last three years, the research project: "Geosites, geoparks contribution to sustainable development" aiming at recording and designating geosites and potential geoparks, as a means to sustainable development, funded from the $3^{\text {rd }}$ Community Support Framework (CSF) programme, is developing at the Institute of Geology and Mineral Exploration of Greece (IGME).
\end{abstract}

The project, according to its objectives, is divided in the following five sub-projects:

1: Identification, characterization, evaluation of geosites

2: Compilation of a DataBase and a Geographic Information System (GIS) for the geosites, geotrails and potential geoparks in the country.

3: Planning of walking and motoring geotrails around the geosites, in combination with other attractions of biotic, archaeological and cultural interest.

4: Specifications of the geoparks' studies and planning for interpretation, tourism, marketing, development, operation and management. Drafting of complete management proposals for selected areas, in view of their development into geoparks and of their participation in international networks.

5: Promotion of the project's objectives and benefits in international, national level and the local community, businesses and institutions. Compilation of interpretative, marketing material for tourism purposes, and for the community awareness on geological heritage conservation.

The whole project is based on the systematic inventory of the geosites and the compilation of a GISaided database for the geosites, geotrails and potential geoparks. The framework of the research materialization, the procedural steps, as well as the methodological approach for its accomplishment, will be presented in this paper, focussing mostly in the first sub-project methodology as Geosites registration is the base for the whole project.

The geosites, geotrails, potential geoparks Registry compiled with this project will function as a source of information for various uses: national and international level public or private sector projects regarding planning and conservation of nature, education and tourism.

Key words: Geosites, geoparks, geotrails, sustainable development, IGME, geoconservation, geological heritage, geotourism, Greece. 


\section{Introduction}

Greece has an interesting geology-geomorphology, along with active processes, due to its geotectonic emplacement, in the collision zone of two tectonic plates. It is a country with richness and variety in areas for geological heritage conservation (Theodosiou et al, 2006) These areas contain appreciable geological-geomorphologic features and landscapes, some of which are of international importance, while at the same time some are very interesting for tourism development.

Awareness for geosites promotion and protection started systematically since 1995 in Greece. (Drandaki, 1995; Drandaki, Mettos, 1996). Thus, the year 1995 should be considered the starting point for the concept of geological heritage conservation in its entirety and complexity and the development of the relevant terminology (geological heritage conservation, geoconservation, geosites, geotopes, geodiversity, geoparks etc) (Theodosiou-Drandaki, 2000a). The year 2005 could be considered a turning point because IGME Board decided to allocate funds from the $3^{\text {rd }}$ CSF for the "designation of geosites-geoparks".

The new orientation to register and promote geoconservation of the country and the plans to set out actions to conserve and enhance the geodiversity of particular areas (Dorset County Council, 2005), were a challenge to be achieved and to put some steps forward the geological heritage conservation in Greece. The 'Action Plan' process for two areas (Lavreotiki and Vikos-Aoos), builded upon an inventory to determine management requirements for the different geodiversity elements, it defined long-term objectives and short-term targets and identified human and financial resources necessary to achieve these (JNCC, 2004). It took ten years to develop the idea of geological heritage conservation into something concrete, a relatively justified period as new ideas need time to be accepted (Theodosiou, 2007).

But, "A mind once expanded with a new idea never regains its original proportion". All the more IGME in 2005 had already ten years experience in geological heritage promotion, education and training (Drandaki et al, 1999). It had as well the geoscientific information, the personnel and the infrastructure for the accomplishment of this new research project. It's obviously thus, the most appropriate organization for this infrastructure research, stimulating and harmonizing all efforts in the domain. IGME was also and still is, collaborator of UNESCO in geoscientific matters, the International Union of Geological Sciences (IUGS), and ProGEO National representative, as well as coordinator of the IUGS-UNESCO-ProGEO “Geosites" initiative, in Greece (Theodosiou-Drandaki, 2001; Theodosiou-Drandaki et al, 2001). The "Geosites" initiative set up by IUGS for the systematic inventory of the most important geological sites, active since 1996, it was undertaken by the Global Geosites Working Group. It aimed to involve the whole geological community in geoconservation, as well as to support any national or international initiative to protect geodiversity, a resource that is underestimated and completely unrenewable (ProGEO-Wimblendon et al, 1998). This inventory focuses mainly on the needs of the geological sciences research and education; there can be no science and education without site conservation, as it is well known (Theodossiou-Drandaki, 2000).

It's worth mentioning here the wider framework regarding geosites-geological heritage conservation and geoparks establishment (Drandaki, 1996; Theodossiou-Drandaki \& Foundou, 1997):

\section{On International Level}

- UNESCO: a. Cultural and Natural Heritage Convention and attempt to include geological sites in the list (Cowie, 1993; Cowie \& Wimbledon, 1994), b. Global Geoparks network (Patzak and Eder, 1996; Patzak and Eder, 1999).

- IUGS Geosites initiative.

- ProGEO: European Association for geological-geomorphologic heritage conservation.

- European geoparks network. (Zouros, 2004; Zouros ed., 2007). 
- Council of Europe: recommendation on conservation of the geological heritage and areas of special geological interest (Adopted by the Committee of Ministers on 5 May 2004).

In National Level

- Cultural and Natural Heritage Convention of UNESCO (1972) ratified by Law 1126/30-11981, G. 32/A/10-2-81.

- Environmental Legal Framework 1650/86.

- Lesvos petrified forest: Founder European geopark in 2000, Global geopark in 2004.

- Psiloritis Natural Park: European geopark in 2001, Global geopark in 2004.

- Chelmos-Vouraikos National park: European and Global Geopark in 2009.

- Geological-Geomorphologic Heritage Committee of the Greek Geological Society, established in 2005.

- Hellenic Ministry of Environment, General Town Planning and Open Town Organization Urban Plans, M.D. 27691/14-09-07 (G. 1902/B/07).

\section{Methodology}

The research project objectives have been the designation of Geosites and the compilation of proposals for Geoparks establishment, as well as relevant tasks. In order to accomplish these objectives it was divided in five sub-projects, running with a differentiation in time from one to another. Thus, needed acquisition and elaboration of data could be accomplished. Mentioned sub-projects are the following:

2.1: Identification, evaluation, classification and systematic registration of greek geosites.

2.2: Compilation of a database (DB) and a Geographic Information System (GIS) for the geosites, geotrails and potential geoparks in the country.

2.3: Planning of walking and motoring geotrails.

2.4: Specifications of the geoparks' operations, interpretation, tourism, marketing, development and management planning. Application dossiers for the European and Global UNESCO geoparks networks.

2.5: Production of appropriate material task either for scientific or awareness raising purposes.

This paper will focus mostly on the first sub-project methodology as Geosites registration is the source of information for the whole project.

Project research started in May 2006 with a budget of 600.000 E. Around 25 various professions geoscientists of IGME have been involved, either from the Central Services or from the regional Departments of the Institute.

\subsection{Identification, evaluation, classification and systematic registration of greek geosites}

The objective of this stage is primarily the inventory and recording of Geosites for the compilation of a dynamic Geosites Registry that will represent the geodiversity of the Greek territory. The preparation followed a number of steps, aiming at the mutual updating and feed backing in the project team, coordination of actions, exchanges of views and considerations, trying in that way to achieve the better grade of consensus and common outlook for the project running.

More detailed, the preparation steps have been: 
- Quest of theoretical relevant research and good practices, or examples and experiences from other countries.

- Set up of research teams.

- Supporting actions: Two plenary and a number of partial technical meetings, as well as e- communication in a regular basis.

- Promotion actions (meetings, conferences), aiming at the information and sensitization of the geoscientific and the broader community for the project concept, the geological heritage conservation and interpretation.

- Training of the project research team in geological heritage interpretation theory and good practices. A workshop organization with Lavrion area as a case study (Veverka, 1998; Theodosiou, 2007a) took place.

For the higher possible standardization and normalization of collected information, the groups of scientists involved in the project were provided with:

- 1. An instructions sheet. Detailed and elaborated instructions how this inventory should be done. These instructions revised periodically, with decisions taken from the project steering committee, as the project was advancing and theory become reality.

- 2. A geosite protocol form, with a detailed series of attributes to be filled in. Criteria for selection (Gonggrijp, Boekschoten, 1981; Duff, 1994; Erikstad, 1994; Stevens et al, 1994; Rosengren, 1994; Wimbledon, 1996; Gonggrijp, 1997; Macadam, 1998; Theodosiou-Drandaki, 1999; Diakantoni et al 1999\&2000; Drandaki et al, 2000; Gray, 2004; Theodosiou et al, 2006) classification and evaluation (Harley, 1994; Haaf, 1995; Junta de Andaluzia, 2001; Kasinski et al, 2004;) were set out according to following values: scientific, educational, and tourist-cultural.

- 3. A list with the Greek Frameworks for geosites. Defined with IUGS/ProGEO Geosites initiative and published in Congresses (ProGEO-Wimbledon et al, 1998; Theodosiou-Drandaki, 2001; Theodosiou-Drandaki et al, 2001; Drandaki-Theodosiou, et al, 2003).

-4. A list with potential geosites, for specific area of each team, compiled previously from field experience, bibliographic references, maps etc (Theodosiou-Drandaki, 1997; Bornovas, 1999; Theodosiou-Drandaki, 1999a; Drandaki et al, 2000; Fassoulas 2001; Theodosiou-Drandaki et al, 2001; Theodosiou-Drandaki, Drandaki eds, 2001; Velitzelos et al, 2002).

The basic document for Geosites registration it's obviously the Geosites inventory protocol form $(\bullet 2)$, which will be described in more detail subsequently:

As already mentioned this sub-project aimed at a Geosites inventory. Data regarding each recorded geosite should fill in the specific geosite protocol form prepared for this purpose. The aim was to test this analytical tool, the geosite protocol form, which should be used by a big number of geoscientists with different specializations, in order to collect structured and the most possible standardized information for the DB and GIS compilation. Obviously it was the basic infrastructure for this sub-project and subsequently the whole project. Parameters taken into consideration during its preparation were:

- The previous international and national experience (Ellis (ed) et al, 1996; Zagorchev et al, 1996; Junta de Andaluzia, 2001). In Greece the first Geosites inventory protocol form appeared 3-lingual in the proceedings (Theodosiou ed, 1999a) of the $1^{\text {st }}$ meeting on geological-geomorphological heritage conservation, which took place in Syros island, in the framework of Ermoupolis Seminars, on 13-15.7.06.

- The evolution of geosite concept (holistic considerations of nature, science social definition, sustainable development, environmental education, alternative tourism). 
- The perspective to define areas as potential geoparks (experience acquired from close cooperation with UNESCO Earth Sciences Division, for the compilation of national geoparks establishement guidelines, as well as from cooperation with ProGEO) (Theodosiou-Drandaki, 2003).

The form asks for information of various nature either geographic, administrative, geoscientific, environmental, etc.

Such a form already has been prepared during previous years, in our effort to register geological sites in a voluntary basis. For the project specific purposes, it has been updated with new fields concerning suggestions for practical management, sustainable development principles, holistic approach, in fact with new concepts for the geosites and for the development of geoparks.

It is divided in four parts: a first part with fields asking for detailed information concerning the geosite itself, contains five blocks with 76 questions totally, while the second part searching for information for the area where the geosite is located, it contains one block with 22 questions. A small third part with five open questions follows for those interested to express opinions, ideas for some topics such as practical management of the geosite, avoidance of improper use in case of tourism, needed protection measures, etc. and a smaller forth part asking for accompanying documents (report, photos-sketches, bibliography).

Most questions are answered marking a v, e.g. for the question Significance of geosite, one of the following could be marked with a $\mathrm{v}$ as an answer: Universal, European, National, regional, local. Most of questions have one of 5 potential answers, in order to have comparative, concrete results to be elaborated with statistics afterwards.

As this information should be gathered once, funds are public and limited; attention was paid to obtain the proper quality and quantity, that is: The geosite protocol form duly completed, A geological map in appropriate scale, Photos of the site interests, A report as a free text for questions, suggestions, ideas, proposals not included in the forms.

A number of 1200 geosites have been registered; around 1000 have been entered in the data base and the GIS.

\subsection{Compilation of a Database and a Geographical Information System for the geosites, geotrails and potential geoparks in the country}

All spatial information together with the attributes have been used to create a multi-relational DB and a GIS with geosites symbols libraries, permitting various queries and relationships and serving for the production of multi-purposes, multi-users maps, as well as other selective either digital or printed products on demand.

Above mentioned project results will support a structured National Data Bank (NDB) of geosites and potential Geoparks and a GIS to emerge, which could be pumped to cover various requirements and users' needs in the country. It can be used for science, education and training, as well as for infrastructure works, rational land uses and conservation of local natural features, briefly, in the entire planning, development and conservation system. The Data Bank maintenance and expansion, with a new project including scientists of the whole geoscientific community, can justify author's expectations for IGME to operate as a Geosites and potential Geoparks National Data Bank (G_GNDB) and Geosites-Geoparks Documentation Center (G_GDC). (Copp, 1994; Ellis (ed) et al, 1996; www.lgt.lt; Miskiewicz, 2004; http://www.geology.cz/extranet-eng/geodata/databases/localities). 


\subsection{Planning of walking and motoring geotrails for potential geoparks}

Applying certain criteria in the recorded geosites DB, a number of areas have been revealed. Information needed to respond to these criteria apparently was given from previously mentioned Geosites protocol forms.

Selection Criteria can be determined from the definition of the geoparks and the prerequites for a geopark establishment (Patzak, Eder, 1996; Zouros et al, (eds) 2003; UNESCO, 2003+2004; Jordan et al, 2004; Theodosiou-Drandaki, 2004; Theodosiou-Drandaki, 2004a). Thus, the following are the criteria applied:

- important geoscientific values: one-two geosite of international significance, with representativity, high scientific value, superb features, mosaics of geological features representative of the area, its geological history, events or processes.

- other values (cultural, natural, archeological etc).

- Certain extent.

- certain management, access.

- certain infrasructure, facilities.

- protection at least partial.

- interest and cooperation of local people and local authorities.

A geopark is an area with diversity and interest in Geosites but also with People, Other values, Infrastactures existing and/or "builded" gradually, Management structures, An information, reception center, Activities, accommodation places, points to eat, enjoy etc., in a way to have a positive effect in the local economy (Zouros et al, (eds) 2003). One or even more isolated geosites, an isolated walk, without opportunity for access, lack of variety, values, density of Geosites, lack of other interests in the area, without interest of the local community for tourism development is not a geopark. We cannot have a geopark from zero. Nevertheless Geosites should be designated and eventually protected in a physiocratic approach, Geoparks is a more antropocentric approach and includes economic and social values.

14 areas have been initially defined ((Patzak, Eder, 1996; Zouros et al, (eds) 2003; UNESCO, 2003+2004;) with geoparks potential for further study, in the framework of the project, the following:

1. Maronia area, 2. S. Thassos island, 3. N.W. Chalkidiki, 4. Olympos area, 5. Vourinos mountain, 6. Meteora, 7. Pindos mountain, 8. Aoos-Vikos area, 9. Kokkinopilos area, 10. Acheron, 11. N. Peloponnisos, 12. Lavreotiki, 13. W. Crete island, 14. Nisyros inland.

Availability of scientists, time, budget, and technical means gave priorities to the following areas for the pilot geotrails design and relevant publication geotrails cards.

1. Maronia area, 2. S. Thassos island, 3. Aoos-Vikos area, 4. Kokkinopilos area, 5. Acheron, 6. Lavreotiki, 7. W. Crete island, 8. Nisyros inland.

These areas constitute those with potential to evolve to geoparks according to the referred in the previous page criteria.

\subsection{Preparation of specifications of the geoparks' operations, interpretation and management planning}

For two of the above mentioned areas, Aoos-Vikos area and Lavreotiki, of outstanding values, but also with maturity grade of management plans, local authorities and people involvement, to serve 
for local sustainable development, occurred in higher degree. Geoparks studies were undertaken for those two areas, in the framework of the $4^{\text {th }}$ sub-project.

Specifications for these two geoparks studies have been prepared following a model, as well as the requirements of European and Global Geoparks Networks (Patzak, Eder, 1996; Mattig, 2003; Zouros et al, (eds) 2003; UNESCO, 2003+2004, Theodosiou-Drandaki, 2004a). Later the geoparks studies have been compiled concerning operation, interpretation, tourism, management and development planning. Applications dossiers for those two areas to be included in the European and in the UNESCO Global Geoparks Networks have been also compiled and duly forwarded to appropriate Bureaus (Theodosiou et al 2009, Theodosiou et al 2009a). These candidature dossiers with all enclosures are to be found at www.igme.gr. Joining the European and the Global Geoparks Networks will give opportunities for science and conservation but also for the sustainable development of the area through geotourism.

\subsubsection{Lavreotiki peninsula geopark, Attica region, Central Greece}

The Geopark is located in Lavreotiki -a peninsula in the SE part of the Prefecture of Attica, within a distance of approximately $60 \mathrm{~km}$ from Athens, the capital of Greece. The territories of two Municipalities (Municipality of Lavreotiki and Municipality of Keratea) and of one Community (Community of Agios Konstantinos) constitute the total area of the candidate Geopark, where 49 geosites have been identified so far (Janikian, 2009; Theodosiou et al, 2009).

Marbles, mica schists, phyllites, is the geological setting in a complex composition and tectonic relation (Photiades et al, 2007).

Intensive activity started with silver exploitation since 3.500 b.C., culminated in 5th, 4th c. B.C., followed by welfare and prosperity of Athenian Democracy. After 3rd B.C. degradation started. Around 1860 started the new history of the exploitation. The area of Lavreotiki is famous worldwide for the exploitation of the mixed sulphide ore deposits and the abundance and variety of mineralogical specimens. Mineral names as Lavriotite, Kamarizite, Ktenasite, Thorikozite, Serpierite originated from the area of Lavrion; these minerals were discovered here, and are included in the collections of several well known mineralogical museums in a worldwide scale. During ancient times, the profit obtained from the exploitation of mines contributed greatly to Greek and European culture development. Nowadays, specialists in the domain of Economic Geology and Mining are impressed from the extremely advanced mining and metallurgical technology applied during antiquity as it is evident from archaeological findings. The significant extent of the ancient mining activity in the area is shown by the abundance of mining and metallurgical wastes. (Dimou, Perdikatsis, 2001).

All the above mentioned facts witness the special geological-mineralogical setting and geodiversity of the area under concern. In addition and intimately interconnected with it the archaeological and cultural setting is of great interest. The biotic environment as well, is of outstanding beauty and value as the area hosts a National Park (Sounio National Park) and two Natura 2000 sites with several types of important habitats. (Presidential Decree for the establishment of the national park -Gazette 80/A/26-3-1974 and Gazette 121/D/19 of February 2003,) (Philotis D.B.; Greek portal for Biodiversity).

The conclusion is that the area of Lavreotiki is considered as a geological, natural and cultural heritage of international significance that can be appreciated through conservation, education and geotourism. This precious heritage, highlighted, protected and managed properly, will be enjoyed by people all over the world, who wish to visit it and learn more about it. 


\subsubsection{Vikos-Aoos Geopark Epirus region, N.W. Greece}

The Geopark area is mainly mountainous, and lies within the administrative boundaries of the following local authorities: Municipality of Konitsa, of Kentriko Zagori, of Tymfi and Community of Papigo, where 44 geosites have been identified so far (Paschos, Nikolaou, Papanikos, 2009).

There is a great variety of geosites in the area from a wide range of geological processes, which compose a picture of great aesthetics with high scientific and pedagogical interest. Geodynamic processes are very important and result to a very impressive landscape with canyons and huge faults (Astraka, Konitsa). Neogene and Quaternary quick ascending movements, combined with strong vertical erosion caused two of the most impressive and deep canyons in the world. Voidomatis (or Vikos) and Aoos rivers flow through them. The wealth of geological diversity resulted in numerous testimonies of the geological history of the area imprinted in a strongly dissected morphology and landscape: karstic springs, glacial age features (lakes), river terraces, caves, limestone lithostratigraphic changes, paleolithic remnants are very well combined with stone bridges, stone-paved walks, picturesque traditional stone-built villages with very rich vegetation. A great number of designated geologists of several countries dedicated a big part of their life studying the area fascinating geology. The relevant bibliography richness approves it. (Theodosiou et al, 2009a).

It is one of the most important areas at the national and European level, as it uniquely combines the natural (habitats, flora, fauna, landforms, hydrography and landscape) and long lasting human environments (traditional settlements, cultural and historic features), as well as unique cultural elements (folk music, popular - traditional arts, etc.) and architectural features (houses, bridges, etc.). Pindos Mountain is of particular ecological interest, because of the unique diversity of species and ecosystems, which are rare in Greece and Europe. The former National Park of Vikos and Aoos gorges (recently incorporated into the broad Northern Pindos National Park) and a number of sites included in the European Ecological Network NATURA 2000, is a clear evidence of its significance. (in Theodosiou et al, 2009a).

The area is already a well-organized tourist destination but the geological framework is evidently missing from interpretation means. Thus its promotion as a geopark will give an additive value and an alternative interest with scientific, pedagogical content to the tourist product.

\subsection{Production of appropriate material either for scientific or awareness raising purposes}

Promotion of the project's objectives. Interpretative, marketing, awareness material production to sensitize the politicians, the stakeholders, the public, NGO's, the tourist sector.

\subsubsection{Cards of Geotrails in Greece}

The series "Geotrails in Greece" (Theodosiou, ed. 2009) is a pilot publication for six Greek areas: Thassos, Maroneia, Epirus (Vikos, Acheron, and Kokkinopilos), Lavreotiki, Nissyros, W. Crete, Gavdos. It is accompanied with in situ panels and an interactive application at the Museum of IGME. Survey form of this publication and relevant in spot signs is to be found at http://www.igme.gr

\subsubsection{Atlas of Geosites and potential geoparks in Greece, 1 st edition}

It contains several kinds of maps concerning geosites, geotrails and geoparks (Theodosiou, 2009).

\subsubsection{Panorama of Geosites, 1 st edition}

It contains a brief description and photos of around 400 geosites (Theodosiou, 2009a). 


\subsubsection{Cards, Leaflets, Calendar 2010}

\section{Conclusions-Results}

The Registry of geosites currently under construction will function as a source of information for every use: public or private sector projects in national and international level, for the development, planning and conservation of nature and heritage, environmental education, and for tourism.

Planning of geotrails around the geosites, in combination with other attractions of biotic, archaeological and cultural interest, as well as compilation of interpretative, awareness printed material is one of the objectives of the project. Same material in DB and GIS-aided digital form is used for applications, exploiting the potential of multimedia and interactive technologies, to attract the interest of the visitor on the geological history and at the time entertain him.

Development and management proposals for geoparks in selected sites, could be implemented by the local councils or other relevant entities, providing social and economic benefits to local communities.

Creating the right products will result in the designation of the geological heritage and the establishment of new forms of alternative tourism, a modern tourist trend for the social and economic development of each region.

Designating geosites will also have a positive impact on the awareness and knowledge of geological history at all levels of education, in our country and internationally.

\section{Acknowledgments}

Geoscientists and Technical personnel, involved in the research project, which I thank deeply one by one, follow:

- IGME Central Services: Avdis V., Carras N., Ioakim Chr., Janikian Z., Manakos C., Memou Z., Photiadis A., Psonis C., Stefouli M., Vogiatzakis E., Vougioukalalkis G, Zananiri Ir. Lagodimou M., Marinou A., Vacalopoulou E.

- Eastern Macedonia-Thrace IGME Regional D/ment: Epitropou N., Kossiaris G., Michail C.

- Central Macedonia IGME Regional D/ment: Arvanitidis N., Theodoroudis A. Mantzagri G., Sgouros D.

- Western Macedonia IGME Regional D/ment: Rassios A. Melanidou E.

- Epirus and Ionian islands IGME Regional D/ment: Nicolaou E., Paschos P., Papanikos D.

- Peloponnesus IGME Regional D/ment: Aggelopoulos C., Vagias D. Loupis D.

- Crete island IGME Regional D/ment: ПMK: Athanassouli E., Pavlidou S.

I would like also to thank all colleagues of IGME infrastructures departments for their cooperation. I would extend my acknowledgments to Eleni Kleisiouni, to Enveco S.A. and to OM-EPE collaborators during the project.

\section{References}

Bornovas, I., 1999: The Natural Monuments of Greece. (C) Kaktos, 350 p., in Greek.

Copp, C. J. T., 1994. Developing geological site recording software for local conservation groups. In: O' 
Halloran, D., Green, C., Harley, M., Stanley, M. \& Knill, J. (eds). Geological and Landscape Conservation. Geological Society, London, p. 313-317.

Cowie, J.W., 1993: The global indicative list of geological sites (GILGES): Report of the World Heritage.

Cowie, J.W. \& Wimbledon, W.A., 1994: The World Heritage List and its relevance to geology. Proceedings of the Malvern Conference 1993, p. 71-73.

Diakantoni, A., Drandaki, I., Fermeli, G., Galanakis, Koutsouveli, A., Eder, W., Patzak, M., Martini, G., Page K., D., Hlad, B., Gonggrijp, G.P. 1999\&2000. Geological heritage, Research in Environmetal education and Cooperation in European Level. GRECEL educational pack. Drandaki, I., Fermeli, G., Koutsouveli, A., (eds), Athens, 245 p.

Dimou, E., Perdikatsis V., 2001. Lavrio, a natural Geotechnological \& Mineralogical Museum. Proceedings of the $2^{\text {nd }}$ International Symposium, natural Monuments and Geological Heritage, Theodosiou, Drandaki (ed). 30.6-2.7.97, Molyvos, p. 59-63.

Dorset County Council, 2005: The Dorset Local Geodiversity Action Plan, www.dorsetlgap.org.uk

Drandaki, Ir., 1995. News from Greece. In Progeo NL 2/96, p.6.

Drandaki, Ir., 1996. «Legislation concerning the natural environment in Greece. Historical overview and existing situation». Geologica Balcanica26.1. Sofia 1996, special issues Geological Heritage. Ed. Bulgarian Academy of Sciences, p. 47-50.

Drandaki, I., Diakantoni, A., Eder, W., Fermeli, G., Galanakis, D., Gonggrijp, G.P., Hlad, B., Koutsouveli, A., Martini, G., Page K. \& Patzak, M., 1999. GRECEL, Geological Heritage: Research in Environmental Education and Cooperation in European Level. Proceedings of the 3rd international symposium of ProGEO: towards the balanced management and conservation of the geological heritage in the new millennium. Madrid, 23-25.11.1999. Barettino D., Wimbledon W.A.P, Gallego E.(eds): 227 p.

Drandaki, I., Koutsouveli, A., Fermeli, G., Galanakis, D., Diakantoni, A., Eder, W., Gonggrijp, G., Hlad, B., Martini G., Page K., 2000. Selection criteria and examples of educational geosites. Abstracts proceedings and presentation in GEOTEE symposium Geotouris-geocultural trails and geomythosites. Athens

Drandaki, I., Mettos, Ant., 1996: IGME initiatives for geological heritage conservation. Proceedings of Lesvos petrified forest Conference. Mytilene 4/06.

Drandaki-Theodosiou, I., Nakov, R., Wimbledon, W.A.P., Serjani, A., Neziraj, A., Hallaci, H., Sijaric, G., Begovic, P., Petrussenko, Sv., Tchoumatchenco, Pl., Todorov, T., Zagorchev, I., Antonov, M., Sinnyovski, D., Diakantoni, A., Fassoulas, Ch., Fermeli, G., Galanakis, D., Koutsouveli, A., Livaditi, A., Papadopoulou, K., Paschos, P., Rassiou, A., Skarpelis, N., Zouros, N., Grigorescu, D., Andrasanu, Al., Hlad, Br., Herlec, U., Kazanci, N., Saroglu, F., Dogan, A., Inaner, H., Dimitrijevic, M., Gavrilovic, D., Krstic, B., Mijovic, D., 2003. IUGS Geosites project progress - A first attempt at a common framework list for south-eastern European Countries. In: Parkes. M.A. (ed) «Natural and Cultural Landscapes: the geological foundation», Royal Irish Academy, Dublin, p. 81-89. ISBN 1904890008.

Duff, K., 1994. Natural areas: an holistic approach to conservation based on geology. Geological and Landscape Conservation. In: O'Halloran DG, Harley C, Stanley M, Knill J, (eds). Geological and Landscape Conservation. London: Geological Society, p. 121-126.

Ellis, N.V., (ed), Bowen, D.Q., Campbell, S., Knill, J.L., McKirdy, A.P., Prosser, C.D., Vincent, M.A., \& Wilson, R.C.L, 1996. An introduction to the Geological Heritage Conservation. Joint Nature Conservation Committee, $132 \mathrm{p}$.

Erikstad, L. 1994. Quaternary geology conservation in Norway, inventory program, criteria and results. Actes du premiere symposium international sur la protection du patrimoine geologique. Memoires de la Societe Geologique de France 165: p. 213-215.

Fassoulas, Ch., 2001. Designation and protection of geological monuments in Crete island. In: Proceed- 
ings of the $2^{\text {nd }}$ International Symposium on Natural monuments and geological heritage, p. 260-268. 30.6-2.7.1997, Molyvos, Lesvos.

Greek portal for Biodiversity: http://www.biodiv-chm.gr/information/fol754874/fol855397

Gonggrijp, G.P., 1997. Geotope motivation and selection: A way of objectifying the subjective. In: Amrino P.G. et al (eds), Engineering geology and the environment, Balkema, Rotterdam. V.3, p. 2940-2954.

Gonggrijp, GP, Boekschoten, GJ. 1981. Earth science conservation: No science without conservation. In: van Loon AJ, (ed.). Quarternary geology: a farewell to A. J. Wiggers: Geologie en Mijnbouw; p. 433-445.

Gray, M. 2004. Geodiversity - valuing and conserving the abiotic nature. Chichester: Wiley, 434 p.

Haaf, Br., 1995. A research methodology on geomorphological assets in the Vosges - France. In Proceedings of Geomorphology and Environmental Impact Assessment, Milano 26.2-2.3.1994. Marchetti, M., Panizza, M., Soldati, M. \& Barani, D. (ed.). Journal Quaderni di Geodynamica Alpina e Quaternaria, vol. 3, Milano.

Harley, M., 1994. The RIGS (Regionally Important geological/Geomorphological Sites) challenge-involving local volunteers in conserving England's geological heritage. In: O’ Halloran, D., Green, C., Harley, M., Stanley, M. \& Knill, J. (eds). Geological and Landscape Conservation. Geological Society, London, p. 313-317.

Janikian, Z., 2009. Geotrails in Greece: Lavrion and surroundings. Theodosiou, I., (ed.) (C) IGME, Publ. Kaleidoskopio. ISBN 978-960-98903-2-8.

JNCC, 2004. Earth Heritage, World Heritage publication.

Jordan, P., Hipp. R., Reynard, E, 2004. La protection de geotopes et la creation de geoparks en Suisse. In : Reynard, E., Pralong, J.-P. (eds). Paysages geomorphologiques, Travaux de recherches N. 27, 2004, 258 p.

Junta de Andaluzia, 2001. Propuesta de Estrategia Andaluza de Conservacion de la Geodiversidad, 104 p.

Kasinski, J. R. Kozma, J., Gawlikowska, E., 2004. Geotopes of the proposed Muskau Arch Geopark - Inventory, classification and evaluation. Polish geological institute Special papers, 13 (2004), p. 73-88. Proceedings of the conference "Geological heritage concept, conservation and protection policy in Central Europe".

Macadam, J., 1998. The criteria for RIGS designation. In: Worcester P.G. Ol. (ed.), proceedings of the first UK RIGS conference, p. 217-223.

Mattig, U., 2003. National Geoparks in Deutschland. In Jordan p., Heinz, R., Heitmann, P., Hipp, R., Imper, D. (Eds). Geotope - wie schutzen /Geotope -vie nutzen, 7, Hannover, Schriftenreihe der Deutschen Geologischen Gesellschaft, 31, p. 30-32.

Miskiewicz, Kr., 2004. Polish database of the representative geosites for the European Framework. In: Polish Geological Institute Special papers, 13: p. 35-40, Proceeding of the Conference "Geological heritage concept, conservation and protection policy in Central Europe".

Paschos, P., Nikolaou, E., Papanikos, D., 2009. Geotrails in Greece: Vikos-Aoos and surroundings. Theodosiou, I., (ed.), (c) IGME, Publ. Kaleidoskopio. ISBN 978-960-98903-5-9. In Greek and English.

Patzak, M., Eder, W., 1996. «UNESCO GEOPARK» - A New Programme - A new UNESCO Label. In: Zagorchev, I. and Nakov, R. (sp. eds), Special Issue "Geological heritage of Europe” Geologica Balcanica, 28.3-4, p. 33-35.

Patzak, M., Eder, W., 1999. «UNESCO GEOPARK» - New Unesco Programme for the environment and sustainable development, Geologia Insubrica, 4/1, p. 17-18.

Philotis Data Base of the National Technical University of Athens.

Photiadis, A., Karras, N., \& Mavridou, F., 2007. IGME Basic Geological Mapping series 1:50.000 scale, sheet Lavrion. Publ. IGME. 
ProGEO-Wimbledon et al, 1998. A first attempt at a geosites framework for Europe -an IUGS initiative to support recognition of a world heritage and european geodiversity. In: Zagorchev, I. and Nakov, R. (sp. eds), Special Issue "Geological heritage of Europe" Geologica Balcanica, 28. 3-4, p. 5-32.

Rosengren, N.J., 1994. The Newer volcanic province in Victoria, Australia: the use of an inventory of scientific significance in the management of scoria and tuff quarrying. In: O' Halloran, D., Green, C., Harley, M., Stanley, M. \& Knill, J. (eds). Geological and Landscape Conservation. Geological Society, London, p. 105-110.

Stevens, C., Erikstad, L. \& Daly, D. 1994. Fundamentals in earth-science conservation. - Actes du premiere symposium international sur la protection du patrimoine geologique. Memoires de la Societe Geologique de France 165, p. 209-212.

Theodosiou, Ir., 2007: Geological-Geomorphologic heritage conservation-IGME role. Proceedings of IGME personnel syndicate meeting on research policies-IGME role. 8 may 2007, in greek.

Theodosiou, Ir., 2007a. Interpretive training course on geoheritage, case study Lavrio. ProGEO NEWS, $4 / 2007$.

Theodosiou, Ir., (ed.) 2009. Geotrails in Greece, series. (C) IGME, Publ. Kaleidoskopio. In Greek and English.

Theodosiou, I., 2009. Atlas of geosites maps, (C) IGME, under publication.

Theodosiou, I., 2009a. Panorama of geosites, (C) IGME, under publication.

Theodosiou, Ir., Janikian, J., Photiadis, A., Papagrigoriou, Sp., Papadaki, A., Bekiaris, Y., Katsikas, N., Adamantiadou, Sm., Mihas, N., Tortopidis, Ant., Toris, N., Kourouzidis, M., Kotzageorgis G., Haindarlis, M., Sifakis, A., Patelarou, M., Alexaki, M., Katselis, Y., Tentes, G., Kalligosfyri, Ag., Haralambopoulou, M., 2009. The Lavreotiki Geopark Application Dossier for nomination as a European Geopark and as an UNESCO Global Geopark, 30 p.

Theodosiou, Ir., Paschos, P., Nikolaou, E., Papanikos, D., Papagrigoriou, Sp., Papadaki, A., Bekiaris, Y., Katsikas, N., Adamantiadou, Sm., Mihas, N., Tortopidis, Ant., Toris, N., Kourouzidis, M., Kotzageorgis G., Haindarlis, M., Sifakis, A., Patelarou, M., Alexaki, M., Katselis, Y., Tentes, G., Kalligosfyri, Ag., Haralambopoulou, M., 2009a. The Vikos - Aoos Geopark Application Dossier for nomination as a European Geopark and as an UNESCO Global Geopark, 30 p.

Theodosiou, Ir., Fermeli, G., Koutsouveli, A., 2006. Our geological heritage. Publ. Kaleidoskopio, 102 p. and CD, Athens. ISBN 960-7846-61-3, in greek.

Theodossiou-Drandaki, Ir., 1997: Itinerary in Macedonia and Thrace geological heritage: Video tape and CD, production IGME, executed by ERT3. In Greek, English, French.

Theodosiou-Drandaki, Ir. 1999: Criteria for geosites selection. In: proceedings of the $1^{\text {st }}$ meeting on geological-geomorphologic heritage conservation. Hermoupolis, Syros island, 13-15.7.06.

Theodosiou-Drandaki, Ir. (ed), 1999a: proceedings of the $1^{\text {st }}$ meeting on geological-geomorphologic heritage conservation. Syros island, 13-15.7.06.

Theodossiou-Drandaki, Ir., 2000: No Conservation without Education: Key-note speech in the session for education and communication. In: Proceedings $3^{\text {rd }}$ International Symposium ProGEO: towards the balanced management and conservation of the geological heritage in the new millennium. Madrid, 2325 November 1999. Barettino D., Wimbledon W.A.P, Gallego E. (eds) 227 p.

Theodosiou-Drandaki, Ir., 2000a. Terminology concerning geological heritage conservation. In scientific terminology and neologisms bulletin of Athens' Academy (preface, p. 69, 91).

Theodosiou-Drandaki, Ir., 2001. Geological framework for the selection of geosites according with the requirements of the International Union of Geosciences (IUGS) and the European Society for the Conservation of geological geomorphological heritage (ProGEO). Phase 1, preparation of an initial framework at the country level. Proceedings of the 9th International Conference of the Greek Geo- 
logical Society.

Theodosiou-Drandaki, Ir., 2003. Report for Geoparks establishment guidelines, IGME, in greek.

Theodosiou-Drandaki, I., 2004. Conservation of the Geological- Geomorphological Heritage in the spatial planning and land use management', Proceedings of 7th Panhellenic Geographic Conference, Lesvos.

Theodosiou-Drandaki, I., 2004a. Initiatives of the Institute of Geology and Mineral Explorations of Greece for the establishment of geoparks in cooperation with local authorities and UNESCO. Cases of Lavrion-Sounion and Pindos National Parks. Presentation in the first International Conference on Global Geoparks, June 27-29 2004, Beijing China.

Theodossiou-Drandaki, Ir. \& Foundou, Chr., 1997. Geoconservation within the framework of the nature conservation in Greece. Proceedings of the international symposium on engineering geology and the environment (IAEG), Athens 23-27 June 1997, p. 3015-3019.

Theodosiou-Drandaki, I., Papadopoulou-Vrinioti K., Markopoulou-Diakantoni A., 2001. Geological framework for the selection of geosites according with the requirements of the International Union of Geosciences (IUGS) and the European Society for the Conservation of geological geomorphological heritage (ProGEO). 2nd phase, opening a debate in the country, the publication of the framework, improve-completion of the framework. Proceedings of the 9th International Conference of the Greek Geological Society.

Theodosiou-Drandaki, Ir., Drandaki, M., (ed.), 2001. Natural monuments and geological heritage. Proceedings of the $2^{\text {nd }}$ International Symposium. 30.6-2.7.1997. Molyvos, Lesvos.

UNESCO, 2003+2004. Network of National Geoparks seeking UNESCO's assistance. Operational guidelines.

Velitzelos, E., Moundrakis, D., Zouros, N., Soulakellis, N., (Scientific coordination), 2002: Atlas of Geological Monuments in Aegean Sea. (C) Ministry of Aegean Sea, in Greek. ISBN: 960-7859-41-3, 352 p.

Veverka, J., 1998. Interpretive Master Planning. Publ. Acorn Naturalists. California. ISBN 1-881150-01$1,162 \mathrm{p}$.

Wimbledon, W.A.P, 1996. National site selection, a stop on the road to a European Geosite list. Geologica Balcanica. 26.1, Sofia, Mart.1996, p. 5-27.

Zagorchev, I., Drandaki, Ir, Tzancov, Tz., 1996. «IUGS Geosites form for Database on Geological Sites, and proposal for Geosites form of Balkan Geological Heritage List». Geologica Balcanica, special issue «Geological Heritage in South-East Europe». Sofia, p. 9-12.

Zouros, N., 2004. The European Geoparks Network. Geological heritage protection and local development, Episodes, 27 (3), p. 165-171.

Zouros, N. (ed), 2007. European Geoparks. Publ. Natural History Museum of the Lesvos Petrified forest, ISBN 9789607646 91-0, 166 p.

Zouros, N., Martini., G., Frey, L. (eds), 2003. Proceedings of the International Symposium on geological heritage protection and local development. $2^{\text {nd }}$ European Geoparks Network Meeting. Lesvos island 3-7.10.2001.

www.lgt.lt, 2006. Caha geotops.

http://www.geology.cz/extranet-eng/geodata/databases/localities 